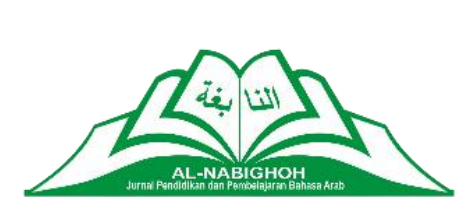

\title{
THE EFFECTIVENESS OF CONTEXTUAL TEACHING LEARNING THROUGH ZOOM IN IMPROVING ARABIC SPEAKING SKILLS DURING COVID-19
}

\author{
Rosita Ilhami ${ }^{*}$, Nur Hasan ${ }^{2}$, Wildana Wargadinata ${ }^{3}$, Muhammad Fadhlan ${ }^{4}$, Ahmad Fikri ${ }^{5}$ \\ 1,3,4 Universitas Islam Negeri Maulana Malik Ibrahim Malang, Indonesia \\ ${ }^{2}$ Universitas Islam Malang, Indonesia \\ ${ }^{5}$ Institut Agama Islam Negeri Kerinci, Indonesia
}

\section{Article Info}

\section{Article History:}

Received: September 2021

Revised: November 2021

Accepted: December 2021

Published: December 2021

\section{*Corresponding Author:}

Name: Rosita Ilhami

Email:

rositailhamioci621@gmail.co $\mathrm{m}$

\section{Abstract}

This study aims to determine the effectiveness of the contextual teaching learning (CTL) method through zoom in improving Arabic speaking skills during Covid-19. This type of research is quantitative research with an experimental approach using a series of research the one-group pretest-posttest design. The object of this research was the

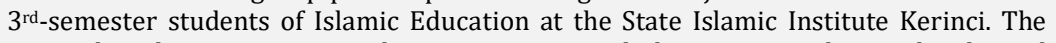
research technique was carried out using tests and observations. The results showed that the significance value of 0.000 <probability 0.05 then $\mathrm{Ho}$ is rejected and $\mathrm{Ha}$ is accepted. Also, there is a significant difference in the mean learning outcomes between the pretest and posttest with the mean paired differences of $-18,500$. These results indicate the average learning outcomes between pretest and posttest $59.56-78.06=$ 18,500 and the difference between these differences is between $-20,618$ to $-16,382$. From these results, it was explained that the contextual teaching learning (CTL) method through zoom was effective in improving the Arabic speaking skills of $3^{\text {rd }}$-semester students of Islamic Education at the State Islamic Institute Kerinci.

Copyright (c) 2021, Rosita Ilhami et al This is an open access article under the CC-BY-SA license 


\section{Introduction}

The discovery of Corona Virus Diseases 19 (Covid-19) in December 2019 has disturbed and become a common enemy of the world community. It causes viruses that can be spread through small droplets from the nose or mouth when sneezing, coughing, or speaking. Therefore, WHO (World Health Organization) recommends following health protocols by maintaining a distance when speaking at least one meter, reducing contact with contaminated objects, avoiding crowds, and nonessential social activities. Also, it is advisable to maintain hygiene by washing hands with soap, wearing masks, keeping a distance, doing work, and other activities from home to break the chain of Covid-19.1

This virus has weakened several sectors of life such as the economy, health, especially education. Therefore, the Ministry of Education and Culture has adopted a policy of implementing learning from home for health reasons and avoiding the risk of Covid-19. Following up on this, the Ministry of Education and Culture issued Circular Letter Number 15 of 2020 concerning relevant home study guidelines to break the covid-19 chain. ${ }^{2}$ Therefore, education experts are competing in finding the most effective learning methods and media to maintain the quality of education during a pandemic.

According to Ritonga, each student requires different treatment, so it is necessary to pay attention to the appropriate learning media. ${ }^{3}$ This demands teachers to be more creative and innovative so that learning can achieve its goals.

For learning during the Covid-19, experts have recommended using applications that support learning from home, such as zoom, google meet, and classroom. However, zoom users consider this application more effective because it provides a share screen feature so that students can view the material directly. Another advantage, zoom facilitates participants to interact even though they don't see each other.

However, learning to use zoom still has shortcomings in practice, so it requires innovation to be more effective. Haqien and Rahman's research on the use of zoom meetings for the learning process during a pandemic found network problems that made learning less effective and bumping on voice distortion

\footnotetext{
1 "Questions \& Answers on COVID-19," diakses 1 September 2021, https://www.who.int/indonesia/news/novel-coronavirus/qa.

2 Kementerian Pendidikan, Kebudayaan, Riset, dan Teknologi, "Kemendikbud Terbitkan Pedoman Penyelenggaraan Belajar Dari Rumah," 29 Mei 2020, https://www.kemdikbud.go.id/main/blog/2020/05/kemendikbud-terbitkan-pedoman-penyelenggaraanbelajar-dari-rumah.

3 Apri Wardana Ritonga, "Pengaruh Media Crossword Puzzle Dalam Meningkatkan Maharah Qira'ah Siswa SMA Islam Sabilillah Malang Boarding School," Studi Arab 11, no. 2 (2020): 73-86, https://doi.org/10.35891/sa.v11i2.2354.
} 
interferes with the learning process, especially speaking skills that require more interaction. ${ }^{4}$

Therefore, researchers argue that solve these problems is necessary to innovate by choosing the right method. Following Nadiem Makarim's statement about the online learning system indirectly forces educators who are not technology-savvy to innovate and make this system an evaluation material to find appropriate learning in online learning.

The principles of bold learning according to the Ministry of Education and Culture include: 1) the safety and health of all school and university communities; 2) provide experience and freedom to students from the curriculum standard notes; 3) directing education to life skills, especially about covid-19; 3) the learning material adapts to the circumstances, conditions and applications of students by region; 5) activities and assignments to adjust the area where students are; Qualitative decisions are not quantitative; 7) promote reciprocal communication patterns between educators and students. ${ }^{5}$

These seven principles implicitly explain that the implementation of online learning (in a network) using electronic systems and the internet aims to protect all school and university communities from the risk of the covid-19 virus. However, it still provides everyone with the right to education with various kinds of learning policies such as materials, learning methods, applications used, assignments, and all supporting the continuity of learning by the abilities, conditions, and local situations of students.

In modern teaching, foreign language learning requires speaking skills to communicate widely with various people from another country. following Nalole, Talking or conversation is an exchange of thoughts or ideas between two or more to get good feedback and understand each other's intentions to be conveyed. ${ }^{6}$

Learning Arabic has the aim of mastering various skills. There are at least four skills, namely: 1) Listening; 2) speaking; 3) reading; and 4) writing. Listening and speaking skills require direct two-way communication from the speaker and listener. Meanwhile, reading and writing skills demand letter media. ${ }^{7}$ This explanation clearly states that each skill requires appropriate treatment to make it easier for students to understand the material and achieve learning standards.

\footnotetext{
${ }^{4}$ Danin Haqien dan Aqiilah Afiifadiyah Rahman, "Pemanfaatan Zoom Meeting untuk Proses Pembelajaran pada Masa Pandemi Covid-19," SAP (Susunan Artikel Pendidikan) 5, no. 1 (2020): 51-56, https://doi.org/10.30998/sap.v5i1.6511.

5 Kementerian Pendidikan, Kebudayaan, Riset, dan Teknologi, "Kemendikbud Terbitkan Pedoman Penyelenggaraan Belajar Dari Rumah."

${ }^{6}$ Darwati Nalole, "Meningkatkan Keterampilan Berbicara (Maharah al-Kalam) Melalui Metode Muhadtsah Dalam Pembelajaran Bahasa Arab," Al-Minhaj : Jurnal Pendidikan Islam 1, no. 1 (2018): 129, https://journal.iaingorontalo.ac.id/index.php/alminhaj/article/view/1027.

7 Sembodo Ardi Widodo, “Model-Model Pembelajaran Bahasa Arab," Al-'Arabiyah 2, no. 2 (2006): 1-14.
} 
The conversation is basic speaking, for both children and parents. Arabic speaking skills are one of the first lessons taught with the aim that students communicate using Arabic. Because it is one way to make it easier to learn to speak is to talk. Therefore, to facilitate learning Arabic by speaking even online, it requires the right method, namely Contextual Teaching Learning (CTL).

Al-Khuli in Alwasilah in Hermawan explained that learning is the processing manifestation of new behaviors and strengthening the old nature to produce implicit explicit experiences. Meanwhile, Skinner and Barlow said that learning is a progressive behavior adaptation. ${ }^{8}$ In conclusion, studying is a process of adapting behavior from not knowing to know. There are various methods to facilitate processing to conveying and receiving learning messages, one of which is contextual teaching-learning (CTL).

CTL is one of the learning methods discussed among academics. It offers academic excellence that can be followed by all students because this method workings of the brain and the principles of living systems that unite concept and practice. ${ }^{9}$

According to Dewey in Satriani and others, CTL is learning that emphasizes students' interests and experiences. ${ }^{10}$ Meanwhile, Pranowo in Tamaji, contextual teaching-learning is education based on the situation and condition of the learner. ${ }^{11}$ In other words, CTL is learning that brings students closer to real-life because it links the material and the real world based on student experiences that can motivate students to do it in everyday life.

Besides, Hull in Davtyan said that the CTL theory would occur if students were able to process new information or knowledge in such a way that it became their frame of reference. He also said that this theory aims to know the meaning according to the context naturally through the mind. ${ }^{12}$ Johnson supporting the previous statement and said that this approach requires the brain to look for the definition of a relationship with the environment. ${ }^{13}$ Based on this statement, hopefully, this contextual teaching-learning can create an attractive and conducive learning environment both indoors and outdoors. The learning objectives of using CTL following to Johnson in Prayogi are: 1) To acquire new knowledge by applying

\footnotetext{
${ }^{8}$ Acep Hermawan, Metodologi Pembelajaran Bahasa Arab (Bandung: PT Remaja Rosdakarya, 2011).

${ }^{9}$ Elaine B. Johnson, Contextual Teaching and Learning: What It Is and Why It's Here to Stay (California: Corwin Press, 2002).

10 Intan Satriani, Emi Emilia, dan Muhammad Handi Gunawan, "Contextual Teaching and Learning Approach to Teaching Writing," Indonesian Journal of Applied Linguistics 2, no. 1 (2012): 13.

11 Sampiril Taurus Tamaji, "Pembelajaran Bahasa Arab Dengan Pendekatan Contekstual Teaching And Learning (CTL)," Prosiding Konferensi Nasional Bahasa Arab 5, no. 5 (2019): 44-49, http://prosiding.arab-um.com/index.php/konasbara/article/view/468.

12 Ruzanna Davtyan, "Contextual Learning" (ASEE 2014 Zone I Conference, Bridgpeort: University of Bridgeport, 2014).

13 Johnson, Contextual Teaching and Learning: What It Is and Why It's Here to Stay.
} 
general matters and relating to specific things. 2) Linking existing knowledge with new intimacy. 3) Train students to be responsible for developing their way of learning. 4) Train students to apply knowledge in everyday life. ${ }^{14}$

Priyatni in Hasnawati said that learning carried out using the contextual method had the following characteristics: 1) Implementation of learning in an authentic context, which means directing learning so that students can deal with problems. 2) Learning provides opportunities for students to do meaningful tasks. 3) Learning is carried out by providing meaningful experiences to students. 4) Learning is carried out through group work, discussion, and mutual correction. 5) Togetherness, cooperation, and deep understanding of each other are enjoyable aspects of learning. 6) Learning is carried out actively, creatively, productively, and requires cooperation. 7) Learning is carried out in a fun way. ${ }^{15}$

Makruf in Arif explains, according to the Arabic term, media comes from the word وسئلة the plural form of الوسط means middle. This word explains as an intermediary between two sides or a link between one another. Meanwhile, according to the National Education Association (NEA), media is a tool that can be stimulated through the five senses to influence the process, in this case, learning. ${ }^{16}$ The opinion above explains the function of learning media which delivering information that affects the process and supports achieving learning objectives.

To deal with Covid-19, education experts recommend using the zoom application in online learning causes this application allows direct verbal and verbal interactions between teachers and students. Also, the zoom has several advantages, namely: 1) Has a capacity of 100 participants. 2) Has a facility to share material through the share screen feature. 3) Have a scheduling facility for meetings through the schedule feature. 4) Can send live meeting images to Google Drive, Dropbox, or file box. 5) Can be accessed via Android, iOS, Windows, and Mac. 6) This aplication is free for 40 minutes. ${ }^{17}$ Although it has several advantages, this application also has disadvantages, such as: 1) wasteful of data quota. 2) The data is not secure.

How to use it is: 1) Prepare and ensure the camera is in good working order. 2) Prepare the mic to increase the sound. 3) Ensure that internet connection is nice and stable. 4) Download the zoom application before using.

${ }^{14}$ Oky Prayogi, Siswantoro Siswantoro, dan Suwarjo Suwarjo, "Pengaruh Contextual Teaching and Learning (CTL) terhadap Hasil Belajar PKn," Pedagogi: Jurnal Pendidikan Dasar 6, no. 5 (2018), http://jurnal.fkip.unila.ac.id/index.php/pgsd/article/view/15634.

15 Hasnawati, "Pendekatan Contextual Teaching Learning Hubungannya dengan Evaluasi Pembelajaran," Jurnal Ekonomi dan Pendidikan 3, no. 1 (2006), https://doi.org/10.21831/jep.v3i1.635.

16 Muh Arif dan Eby Waskito Makalalag, Pengembangan Media Pembelajaran Bahasa Arab (Solok: Insan Cendekia Mandiri, 2020).

17 "Pemanfaatan Aplikasi Zoom," Guru Berbagi, diakses 5 Februari 2021, https://ayoguruberbagi.kemdikbud.go.id/artikel/pemanfaatan-aplikasi-zoom-1/. 
Also, several studies argue that zoom is the right learning medium. Following Fakhruddin's research on improving students' speaking skills using the zoom application can improve student speaking. ${ }^{18}$ Then the study of Herawati, et al. says the zoom application is one of the breakthroughs in learning and increasing knowledge, especially in Indonesian speaking skills material cause this application allows students to interact and provide arguments. ${ }^{19}$

Based on the explanation above from advantages and disadvantages of using the zoom application is one of the recommended applications to make online learning easier during a pandemic.

Arabic Speaking

As explained earlier, one of the language skills is speaking. Speaking is one of the hard skills for foreign language learners to become excellent in language through speaking. This skill will be useful for connecting and communicating with various people from all over the world. ${ }^{20}$ Besides, speaking skills are the process of conveying messages of thoughts or feelings through verbal or sentence. ${ }^{21}$ Also, to master Arabic speaking skill it is necessary to know the following below: 1) Know what to say 2) Must increase self-confidence and be diligent in practicing conversations using Arabic. 3) Must increase Arabic literacy in news, magazines, and others. ${ }^{22}$

Also, Herawati explained that there are several obstacles in improving speaking skills, including: 1) Students do not have self-confidence because they are ashamed and afraid of being wrong. 2) Unable to find a topic of conversation. 3) Environmental factors that do not support Arabic conversations. 4) Not accustomed to using foreign languages and afraid to practice it. ${ }^{23}$

Therefore, teachers need to facilitate learning Arabic language skills by creating a conducive environment, helping students to increase their confidence in speaking, and developing skills in constructing knowledge in their environment using Arabic.

\footnotetext{
${ }^{18}$ Afief Fakhruddin, "Meningkatkan Kemampuan Speaking Mahasiswa Menggunakan Aplikasi Zoom," Prosiding Seminar Nasional Pendidikan 2 (2020): 581, https://prosiding.unma.ac.id/index.php/semnasfkip/article/view/367.

${ }^{19}$ Tuti Herawati, Bambang Gulyanto, dan Nila Sudarti, "Penerapan Aplikasi Zoom Pada Materi Keterampilan Berbicara Mahasiswa Bahasa Indonesia," Seminar Nasional Multi Disiplin Ilmu Universitas Asahan 2 (2020), http://jurnal.una.ac.id/index.php/semnasmudi/article/view/1528.

${ }^{20}$ Mohammad H. Al-khresheh, Ahmad Khaerurrozikin, dan Abdul Hafidz Zaid, "The Efficiency of Using Pictures in Teaching Speaking Skills of Non-Native Arabic Beginner Students," Universal Journal of Educational Research 8, no. 3 (2020): 872, https://doi.org/10.13189/ujer.2020.080318.

${ }^{21}$ Ria Meri Fajrin, Walfajri Walfajri, dan Khotijah Khotijah, "Penerapan Metode Langsung Dalam Meningkatkan Keterampilan Berbicara Bahasa Arab," Lisanuna: Jurnal IImu Bahasa Arab Dan Pembelajarannya 10, no. 2 (2021): 342, https://doi.org/10.22373/ls.v10i2.8834.

22 Sueraya Che Haron, "The Teaching Methodology of Arabic Speaking Skills: Learners' Perspectives," International Education Studies 6, no. 2 (2012): 55-62, https://doi.org/10.5539/ies.v6n2p55.

${ }^{23}$ Herawati, Gulyanto, dan Sudarti, "Penerapan Aplikasi Zoom Pada Materi Keterampilan Berbicara Mahasiswa Bahasa Indonesia."
} 
Based on the researchers' observations at the Kerinci State Islamic Institute, the researchers found obstacles in learning Arabic speaking skills during the Covid-19. Therefore, it is necessary to have appropriate learning methods and media to facilitate online learning Arabic by speaking.

Based on the explanation above, this study aims to see the effectiveness of contextual teaching-learning (CTL) through zoom to improve Arabic speaking skills during the pandemic for 3rd-semester students of Kerinci State Islamic Institut the field of Arabic studies.

\section{Method}

This research uses quantitative research with an experimental approach. According to Creswell, an experiment is to test a theory or method on individuals or groups of research objects to find the results understudy after being given different treatments. ${ }^{24}$ It means the research aims to know the results after getting the treatment.

While the research design using the one-group pretest-posttest design by giving pretest before and posttest after giving treatment. Data collection technique by using tests and observations. This study only used one experimental group, namely the 3rd semester Islamic Education students of the Kerinci State Islamic Institute with 34 students.

\section{Result and Discussion}

The first step in this research is observation and finding that learning Arabic on speaking skills was not carried out properly because learning is only by WhatsApp. Daheri et al. Also explain the same thing that the use of Whatsapp in learning is not very effective and still requires further evaluation because learning while WhatsApp needs more innovation from the educator to improve the quality of learning. ${ }^{25}$ In addition, WhatsApp is not friendly to students in remote areas because it requires stable internet, cellphone memory large enough to accommodate all chats in the group, and requires patience to scroll through learning information from the beginning in the group chat room. ${ }^{26}$ In this case, the process is only providing material, and students record conversations using voice notes. Like the picture below.

${ }^{24}$ John W. Creswell, Educational Research: Planning, Conducting, and Evaluating Quantitative and Qualitative Research (Merrill, 2005).

${ }^{25}$ Mirzon Daheri dkk., "Efektifitas WhatsApp sebagai Media Belajar Daring," Jurnal Basicedu 4, no. 4 (2020): 775, https://doi.org/10.31004/basicedu.v4i4.445.

26 Nurul Astuty Yensy, "Efektifitas Pembelajaran Statistika Matematika Melalui Media Whatsapp Group Ditinjau Dari Hasil Belajar Mahasiswa (Masa Pandemik Covid 19)," Jurnal Pendidikan $\begin{array}{llllll}\text { Matematika } & \text { Raflesia } & 5, & \text { no. } & 2 & \text { (2020): }\end{array}$ https://ejournal.unib.ac.id/index.php/jpmr/article/view/11410. 
Picture 1. Learning with whatsapp

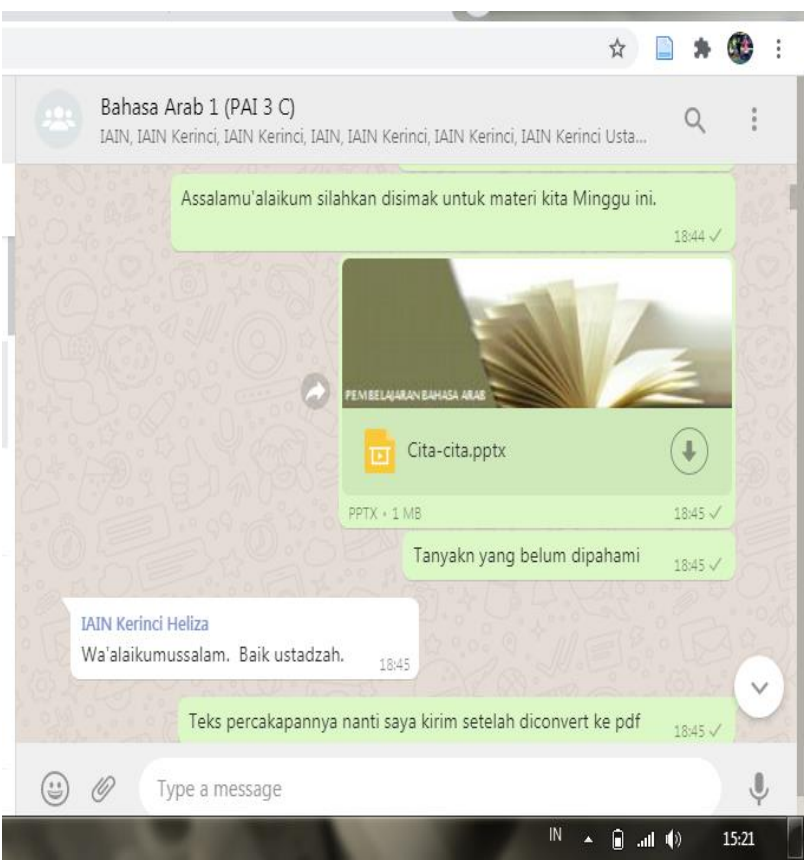

Picture 2. Learning with whatsapp

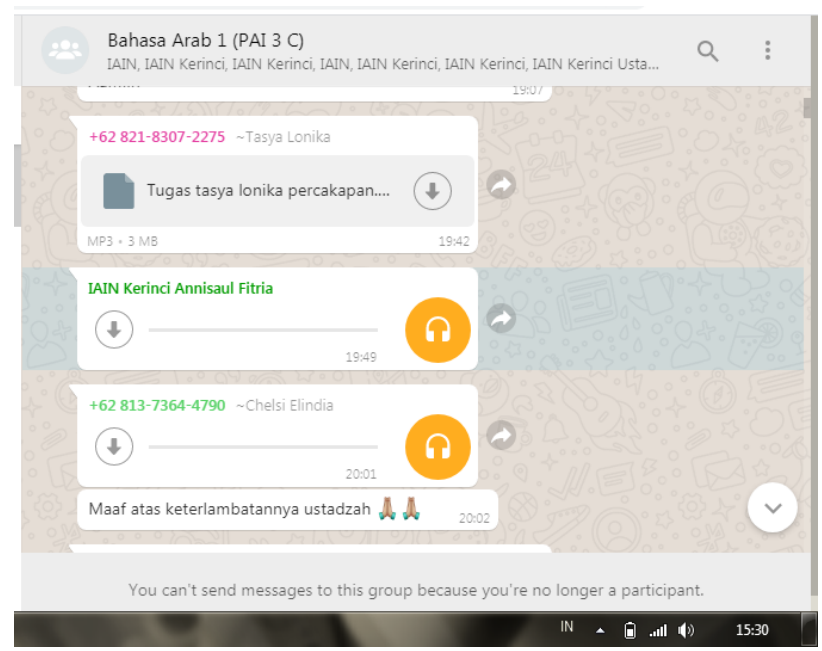

After observing the learning process, the researcher gave a pretest to determine the value of speaking skills before applying to learn using the zoombased contextual teaching-learning method. Furthermore, researchers conducted learning using the zoom-based contextual teaching-learning method. The implementation is as follows: 1) Educators and students are in the same zoom link. 2) Educators provide vocabulary material and conversational texts. 3) Educators ask students to memorize vocabulary. 4) Educators ask students to read dialogue text. 5) Educators ask students to have conversations following the environmental conditions of students. 
Picture 3. Learning with CTL and zoom

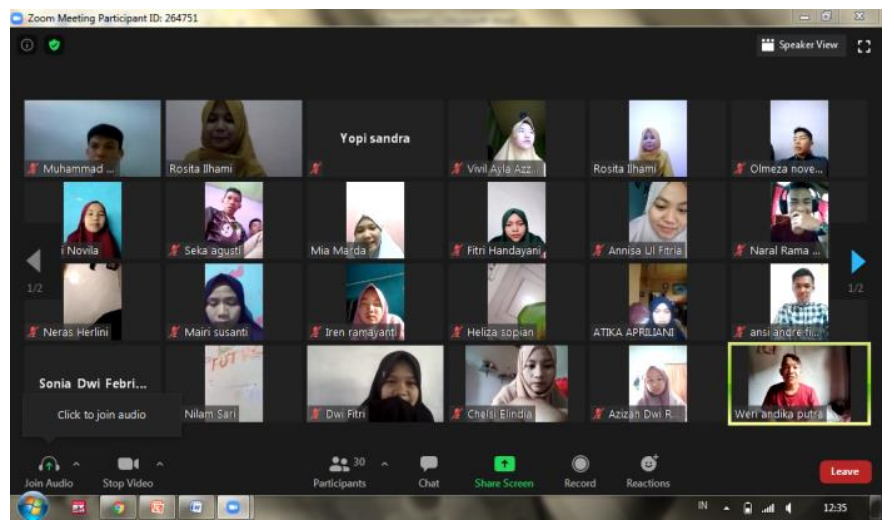

Furthermore, the researcher finding in this research is the posttest score of speaking skills after being taught by zoom based CTL. The results of the pretest and posttest are in the table below.

Table 1. The rusult of pretest and postest

\begin{tabular}{cccccc}
\hline Responden & Pretest & Posttest & Responden & Pretest & Posttest \\
\hline 1 & 60 & 75 & 18 & 60 & 65 \\
2 & 75 & 90 & 19 & 60 & 60 \\
3 & 60 & 77 & 20 & 60 & 65 \\
4 & 60 & 77 & 21 & 60 & 87 \\
5 & 75 & 92 & 22 & 60 & 87 \\
6 & 60 & 75 & 23 & 60 & 80 \\
7 & 60 & 80 & 24 & 60 & 85 \\
8 & 60 & 80 & 25 & 60 & 70 \\
9 & 60 & 65 & 26 & 60 & 82 \\
10 & 60 & 75 & 27 & 60 & 80 \\
11 & 60 & 90 & 28 & 60 & 72 \\
12 & 60 & 87 & 29 & 60 & 75 \\
13 & 60 & 65 & 30 & 60 & 82 \\
14 & 60 & 82 & 31 & 60 & 87 \\
15 & 60 & 87 & 32 & 60 & 70 \\
16 & 60 & 95 & 33 & 60 & 65 \\
17 & 60 & 80 & 34 & 60 & 75 \\
\hline \multicolumn{7}{r}{ Total } & & $\mathbf{2 0 7 0}$ & $\mathbf{2 6 5 9}$ \\
\hline
\end{tabular}

After calculating the score, the researcher found that the students' speaking skills were improved from the mean score of 60,88 in the pre-test to be 78,20 in the post-test. It was supported by the mean score post-test of students' speaking skills was higher than pre-test. 
This study knows the results of studying from the pretest and posttest data. First, the researcher gave a pretest to students before learning using the CTL method through zoom. Furthermore, the researcher gave a posttest after learning using the CTL method through zoom. The following are the results of the normality and homogeneity tests.

Table 2.

Tests of Normality

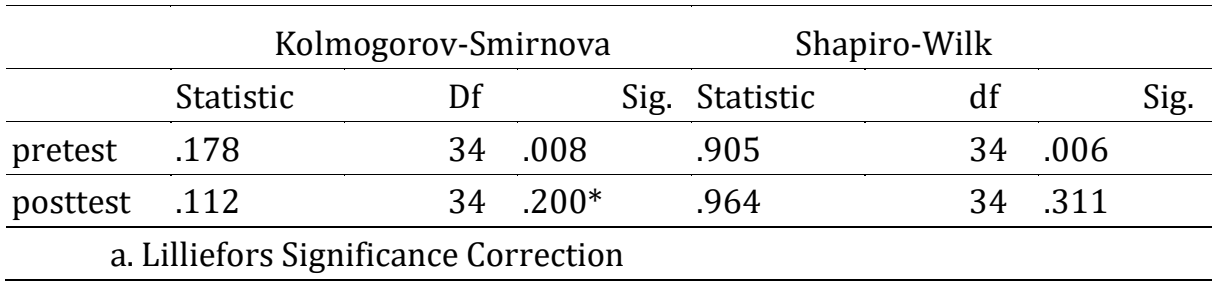

*. This is a lower bound of the true significance.

The output above shows the results of the pretest and posttest variables greater than 0.05 , which means the variables are normally distributed.

Table 3.

\begin{tabular}{clllll}
\multicolumn{5}{c}{ Test of Homogeneity of Variances } \\
\hline \multicolumn{1}{c}{ df1 } & df2 & & Sig. \\
\hline Levene Statistic & 1 & 66 & .014 &
\end{tabular}

The output table above shows a significance value> 0.05. Based on these results, the researcher concluded that the pretest and posttest results were the same and homogeneous. After performing the normality and homogeneity test, the researcher will continue the analysis using the paired sample T-test.

Table 4.

Paired Samples Statistics

\begin{tabular}{llllrc}
\hline & Mean & N & Std. Deviation & Std. Error Mean \\
\hline Pair 1 & Pretest & 59.56 & 34 & 6.200 & 1.063 \\
\cline { 2 - 6 } & Posttest & 78.06 & 34 & 9.260 & 1.588
\end{tabular}

Based on the results, the table above shows that the mean value of learning or mean pretest is 59.56, and the average value for the postest is 78.06, the mark of Std. Deviation at pretest was 6,200 and posttest was 9,260, the value of Std. The mean error for the pretest was 1.063 and for the posttest was 1.588 means value for the pretest was $59.56<78.06$. that is, explaining there is a difference in the average pretest and posttest learning outcomes.

Table 5.

Paired Samples Correlations

\begin{tabular}{llccl}
\hline & & N & Correlation & Sig. \\
\hline Pair 1 & pretest \& posttest & 34 & .761 & .000
\end{tabular}


Based on the output above, there is a correlation coefficient (correlation) is 0.761 with a significance value (Sig.) Of 0.000 <probability 0.05 , meaning that there is a relationship between pretest and posttest.

Table 6.

Paired Samples Test

\begin{tabular}{|c|c|c|c|c|c|c|c|c|}
\hline \multicolumn{7}{|c|}{ Paired Differences } & \multirow[b]{3}{*}{$\mathrm{t}$} & \multirow{3}{*}{$\begin{array}{l}\text { Sig. (2- } \\
\text { df tailed) }\end{array}$} \\
\hline & & \multirow[b]{2}{*}{ Mean } & \multirow{2}{*}{$\begin{array}{l}\text { Std. } \\
\text { Deviation }\end{array}$} & \multirow{2}{*}{$\begin{array}{l}\text { Std. } \\
\text { Error } \\
\text { Mean }\end{array}$} & \multicolumn{2}{|c|}{\begin{tabular}{l}
\multicolumn{1}{c}{$95 \%$} \\
Confidence Interval of \\
the Difference \\
\end{tabular}} & & \\
\hline & & & & & Lower & Upper & & \\
\hline Pair 1 & $\begin{array}{l}\text { pretest } \\
\text { posttest }\end{array}$ & --18.500 & 6.072 & 1.041 & -20.618 & -16.382 & -17.767 & $3 \quad .000$ \\
\hline
\end{tabular}

The table above shows that the significance value of $0.000<$ probability 0.05 then $\mathrm{Ho}$ is rejected and $\mathrm{Ha}$ is accepted. This output concludes that there is an average difference between the pretest and posttest learning outcomes using the CTL method through zoom effective to improve the Arabic speaking skills of 3rdsemester Kerinci Islamic State Institut students in Arabic studies. It has the mean value of paired differences of $-18,500$ shows the learning outcomes between pretest and posttest $59.56-78.06=-18,500$ with the difference between these differences is between $-20,618$ to $-16,382$.

The previous explanations explain the positive effect of using zoom in learning, because the zoom is easy to use, makes the learning atmosphere more interactive, and makes it easier for students and teachers to transfer knowledge. ${ }^{27}$ Alfadda and Mahdi's research mentions several advantages of zoom, for example, everyone can use a webcam and microphone to interact at the same time, and can accommodate up to 3000 participants. ${ }^{28}$ In this case, the researcher will describe as follows:

The positiveness: 1) Make it easier for students and teachers to interact both verbally and non-verbally. 2) Learning materials that relate to student experiences can make it easier for students to understand the material. 3) Students can practice the conversation directly. 4) Learning becomes more active and interesting. 5) Students can construct their existing knowledge in the environment through the practice of speaking Arabic.

${ }^{27}$ HyeJeong Kim, "The Efficacy of Zoom Technology as an Educational Tool for English Reading Comprehension Achievement in EFL Classroom," International Journal of Advanced Culture Technology 8, no. 3 (2020): 198-205, https://doi.org/10.17703/IJACT.2020.8.3.198.

28 Hind Abdulaziz Alfadda dan Hassan Saleh Mahdi, "Measuring Students' Use of Zoom Application in Language Course Based on the Technology Acceptance Model (TAM)," Journal of Psycholinguistic Research 50, no. 4 (2021): 883-900, https://doi.org/10.1007/s10936-020-09752-1. 
In addition to advantages, the use of zoom also has disadvantages, because it is difficult to use for 2 out of 30 students and students lack initiative in learning. ${ }^{29}$ This research also found the disvantages of using contextual teaching-learning through zoom in improving arabic speaking skills, such as: 1) Takes more time in practice, because they cannot practice simultaneously and have to make conversations to practice turns. 2) Less learning duration.

\section{Conclusion}

The principle of contextual teaching-learning (CTL) that brings students closer to experience and real-life makes it easier for students to learn the material and improve their Arabic speaking skills by link the material into their minds and express it naturally. Based on the comparison of learning outcomes from the pretest of 59.56 and post-test 78.06. It explains that the contextual teachinglearning (CTL) method through zoom during covid-19 is very effective. This research still needs further research about has a disadvantage because it only focuses on the effectiveness of learning during the pandemic to improve Arabic speaking skills. Researchers hope that further research can further develop research objects and keep innovating to create active, effective, and quality learning.

\section{Acknowledgment}

At writing this article, the author would like to thank parents who always motivated to continue working. Furthermore, the author would also like to thank Sis Suci who has directed the writing of this article. Also, thanks to kak Ely, Firdaus Juanda, and Ibnu Al Amin who have corrected the writing systematics. Thanks also to Kerinci State Islamic Institute and their 3rd semester students of Islamic Education.

\section{References}

Alfadda, Hind Abdulaziz, dan Hassan Saleh Mahdi. "Measuring Students' Use of Zoom Application in Language Course Based on the Technology Acceptance Model (TAM)." Journal of Psycholinguistic Research 50, no. 4 (2021): 883900. https://doi.org/10.1007/s10936-020-09752-1.

Al-khresheh, Mohammad H., Ahmad Khaerurrozikin, dan Abdul Hafidz Zaid. "The Efficiency of Using Pictures in Teaching Speaking Skills of Non-Native Arabic Beginner Students." Universal Journal of Educational Research 8, no. 3 (2020): 872. https://doi.org/10.13189/ujer.2020.080318.

${ }^{29}$ Guzel R. Nurieva dan Leila M. Garaeva, "Zoom-based distance learning of English as a foreign language," Journal of Research in Applied Linguistics 11, no. Proceedings of the 7th International Conference on Applied Linguistics Issues (ALI 2020), Saint Petersburg, 13-14 June 2020 (2020): 439, https://rals.scu.ac.ir/article_16344.html. 
Arif, Muh, dan Eby Waskito Makalalag. Pengembangan Media Pembelajaran Bahasa Arab. Solok: Insan Cendekia Mandiri, 2020.

Creswell, John W. Educational Research: Planning, Conducting, and Evaluating Quantitative and Qualitative Research. Merrill, 2005.

Daheri, Mirzon, Juliana Juliana, Deriwanto Deriwanto, dan Ahmad Dibul Amda. "Efektifitas WhatsApp sebagai Media Belajar Daring." Jurnal Basicedu 4, no. 4 (2020): 775. https://doi.org/10.31004/basicedu.v4i4.445.

Davtyan, Ruzanna. “Contextual Learning.” Bridgpeort: University of Bridgeport, 2014.

Fajrin, Ria Meri, Walfajri Walfajri, dan Khotijah Khotijah. "Penerapan Metode Langsung Dalam Meningkatkan Keterampilan Berbicara Bahasa Arab." Lisanuna: Jurnal Ilmu Bahasa Arab Dan Pembelajarannya 10, no. 2 (2021): 342. https://doi.org/10.22373/ls.v10i2.8834.

Fakhruddin, Afief. "Meningkatkan Kemampuan Speaking Mahasiswa Menggunakan Aplikasi Zoom." Prosiding Seminar Nasional Pendidikan 2 (2020): 581. https://prosiding.unma.ac.id/index.php/semnasfkip/article/view/367.

Haqien, Danin, dan Aqiilah Afiifadiyah Rahman. "Pemanfaatan Zoom Meeting untuk Proses Pembelajaran pada Masa Pandemi Covid-19." SAP (Susunan Artikel Pendidikan) 5, no. 1 (2020): 51-56. https://doi.org/10.30998/sap.v5i1.6511.

Haron, Sueraya Che. "The Teaching Methodology of Arabic Speaking Skills: Learners' Perspectives." International Education Studies 6, no. 2 (2012): 5562. https://doi.org/10.5539/ies.v6n2p55.

Hasnawati. "Pendekatan Contextual Teaching Learning Hubungannya dengan Evaluasi Pembelajaran." Jurnal Ekonomi dan Pendidikan 3, no. 1 (2006). https://doi.org/10.21831/jep.v3i1.635.

Herawati, Tuti, Bambang Gulyanto, dan Nila Sudarti. "Penerapan Aplikasi Zoom Pada Materi Keterampilan Berbicara Mahasiswa Bahasa Indonesia." Seminar Nasional Multi Disiplin Ilmu Universitas Asahan 2 (2020). http://jurnal.una.ac.id/index.php/semnasmudi/article/view/1528.

Hermawan, Acep. Metodologi Pembelajaran Bahasa Arab. Bandung: PT Remaja Rosdakarya, 2011.

Johnson, Elaine B. Contextual Teaching and Learning: What It Is and Why It's Here to Stay. California: Corwin Press, 2002.

Kementerian Pendidikan, Kebudayaan, Riset, dan Teknologi. "Kemendikbud Terbitkan Pedoman Penyelenggaraan Belajar Dari Rumah," 29 Mei 2020. https://www.kemdikbud.go.id/main/blog/2020/05/kemendikbudterbitkan-pedoman-penyelenggaraan-belajar-dari-rumah.

Kim, HyeJeong. "The Efficacy of Zoom Technology as an Educational Tool for English Reading Comprehension Achievement in EFL Classroom." 
International Journal of Advanced Culture Technology 8, no. 3 (2020): 198205. https://doi.org/10.17703/IJACT.2020.8.3.198.

Nalole, Darwati. "Meningkatkan Keterampilan Berbicara (Maharah al-Kalam) Melalui Metode Muhadtsah Dalam Pembelajaran Bahasa Arab." Al-Minhaj: $\begin{array}{llllll}\text { Jurnal Pendidikan Islam 1, no. } 129 . & \text { (2018): } 129 .\end{array}$ https://journal.iaingorontalo.ac.id/index.php/alminhaj/article/view/1027.

Guru Berbagi. "Pemanfaatan Aplikasi Zoom." Diakses 5 Februari 2021. https://ayoguruberbagi.kemdikbud.go.id/artikel/pemanfaatan-aplikasizoom-1/.

Prayogi, Oky, Siswantoro Siswantoro, dan Suwarjo Suwarjo. "Pengaruh Contextual Teaching and Learning (CTL) terhadap Hasil Belajar PKn.” Pedagogi: Jurnal $\begin{array}{lllll}\text { Pendidikan Dasar no. } & \text { 6, 2018). }\end{array}$ http://jurnal.fkip.unila.ac.id/index.php/pgsd/article/view/15634.

"Questions \& Answers on COVID-19." Diakses 1 September 2021. https://www.who.int/indonesia/news/novel-coronavirus/qa.

R. Nurieva, Guzel, dan Leila M. Garaeva. "Zoom-based distance learning of English as a foreign language." Journal of Research in Applied Linguistics 11, no. Proceedings of the 7th International Conference on Applied Linguistics Issues (ALI 2020), Saint Petersburg, 13-14 June 2020 (2020): 439. https://rals.scu.ac.ir/article_16344.html.

Ritonga, Apri Wardana. "Pengaruh Media Crossword Puzzle Dalam Meningkatkan Maharah Qira'ah Siswa SMA Islam Sabilillah Malang Boarding School." Studi Arab 11, no. 2 (2020): 73-86. https://doi.org/10.35891/sa.v11i2.2354.

Satriani, Intan, Emi Emilia, dan Muhammad Handi Gunawan. "Contextual Teaching and Learning Approach to Teaching Writing." Indonesian Journal of Applied Linguistics 2, no. 1 (2012).

Tamaji, Sampiril Taurus. "Pembelajaran Bahasa Arab Dengan Pendekatan Contekstual Teaching And Learning (CTL)." Prosiding Konferensi Nasional Bahasa Arab 5, no. 5 (2019): 44-49. http://prosiding.arabum.com/index.php/konasbara/article/view/468.

Widodo, Sembodo Ardi. "Model-Model Pembelajaran Bahasa Arab." Al-'Arabiyah 2, no. 2 (2006): 1-14.

Yensy, Nurul Astuty. "Efektifitas Pembelajaran Statistika Matematika Melalui Media Whatsapp Group Ditinjau Dari Hasil Belajar Mahasiswa (Masa Pandemik Covid 19)." Jurnal Pendidikan Matematika Raflesia 5, no. 2 (2020):

65-74. https://ejournal.unib.ac.id/index.php/jpmr/article/view/11410. 